\title{
Survey of Major Wheat Diseases in South Eastern Ethiopia
}

\author{
Getnet Muche Abebele*, Alemu Ayele Zerihun, Tamirat Negash \\ Ethiopian Institute of Agricultural Research (EIAR), Kulumsa Agricultural Research Center, Asella, Ethiopia
}

Email address:

getnetmuche2014@gmail.com (G. M. Abebele)

${ }^{*}$ Corresponding author

\section{To cite this article:}

Getnet Muche Abebele, Alemu Ayele Zerihun, Tamirat Negash. Survey of Major Wheat Diseases in South Eastern Ethiopia. Science Research. Vol. 9, No. 4, 2021, pp. 46-50. doi: 10.11648/j.sr.20210904.11

Received: May 4, 2021; Accepted: July 1, 2021; Published: July 9, 2021

\begin{abstract}
Wheat foliar mainly rusts, and root and foot diseases are important biological constraints to wheat production in Ethiopia especially in Arsi and West Arsi - main wheat belt areas of Ethiopia. Both fungal diseases incurred huge economic losses annually. In 2020 main growing season, assessment was carried out with the stress to ascertain the state of major foliar, root and foot diseases of wheat in Arsi and West Arsi zones of Ethiopia. The assessment result showed yellow rust, septoria leaf blotch and stem rust diseases among foliar; fusarium head blight from spike diseases; eyespot and take all from foot and root were found prevalent. The incidence of foliar diseases viz septoria leaf blotch, yellow and stem rust was $100 \%, 92.7 \%$ and $11.8 \%$ respectively. While take all and eyespot were observed $52.4 \%$ and $48.5 \%$ in the same order. Unlike its incidence, maximum disease severity was caused by yellow rust with higher epidemics on Kubsa and Ogolcho varieties that occupied largest volume in assessed farms. Take- all and eyespots were observed on fields where continuous monocropping is practiced with severity ranges of 0-5 and 0-3 respectively. Thus, it is advisable that much works are needed to train producers to use upto-date released wheat varieties in order to reduce rust diseases and conduct crop rotation and residue management for the control of foot and root diseases thereby decline associated yield losses.
\end{abstract}

Keywords: Yellow Rust, Septoria Leaf Blotch, Stem Rust, FHB, Take-all, Eye Spot

\section{Introduction}

Wheat is the cereal food grain that is produced in the largest land area and the most volume [1] where more than one-third of the world's population uses it as a fundamental food [2]. Globally, wheat is produced in diverse agroecological regions [3] approximately on 218 million hectares of arable land [4]. Wheat plays an important role in everyday life of the world's population and provides over $21 \%$ of the food calories and $20 \%$ of the protein to over 4.5 billion people, which radically minimized poverty and hunger [5] thereby offering a vital role in food security [6].

Ethiopia ranks second in wheat production among subSahara African countries next to South Africa [7]. Wheat is fourth among cereal crops after Tef, maize and sorghum in area coverage and second in production per hectare next to maize [7]. The area of production is expanding in the country, because of its higher productivity and broader adaptation [8,9]. Although the productivity of wheat has increased in the last few years, the mean productivity in
Ethiopia is very low as compared to other wheat producing countries [10]. The national average productivity is estimated to 2.35 tons/ha [11] which is below the world's average. This low yield is attributed to multi faced abiotic and biotic factors [12]. Among the abiotic factors drought, nutrient deficiencies, and water logging in vertisol areas, cultivating unimproved low yielding varieties, low and uneven rainfall, poor agronomic practices, are identified as major threats as well as the biotic stresses like grass weeds and diseases are the major constraints reducing wheat production [13].

Rust diseases of wheat are among the oldest known diseases and yield constraining worldwide [14]. Globally, yellow rust (Puccinia striiformis f tritici), stem rust (Puccinia graminis f. sp. tritici) and leaf rust (Puccinia triticina) are the most damaging diseases of wheat at different levels of epidemics each year [15]. In Ethiopia, yield loss of wheat associated with wheat rust is varied contingent on the degree of susceptibility of cultivars, the time of the initial infection and environmental conditions during epidemic development [16]. For instance, losses have ranged $100 \%$ and 40 to $100 \%$ 
with stem and yellow rust respectively [16].

In addition to foliar disease vitz, rusts, septoria blotch and powdery mildew, wheat is greatly exposed to disease complex especially to; spike disease like fusarium head blight and foot (eyespot caused by Pseudocercosporella herpotrichoides (Fron) Dei.) and root (Take-all caused by Gaeumannomyces graminis var. tritici Walker) diseases in most wheat growing areas of Ethiopia including West Arsi and Arsi mono cropping wheat belts in each growing season $[17,18]$. Therefore, a survey was conducted with the stress to determine the situation of those diseases in Arsi and West Arsi wheat growing areas of South East Ethiopia for rusts, Septoria leaf blotch and fusarium head scab.

\section{Materials and Methods}

Field assessment was carried out in major wheat producing agro ecological districts of Arsi and West Arsi zones of Oromia National Regional State, Ethiopia to determine the fate of incidence, and severity of foliar diseases (rusts, septoria leaf blotch), fusarium head blight and foot and root (eyespot and take all) diseases during 2020 growing season. A total of 60 fields were assessed in 12 districts in two zones. The surveys were made following the main roads and accessible routes in each survey district, and stops were made at every $5-10 \mathrm{~km}$ intervals based on vehicles odometers. Three to five stops were made in each wheat field along a diagonal move at each stop interval.

Table 1. Geographic coordinates (latitude and longitude), and altitude of areas included in the survey.

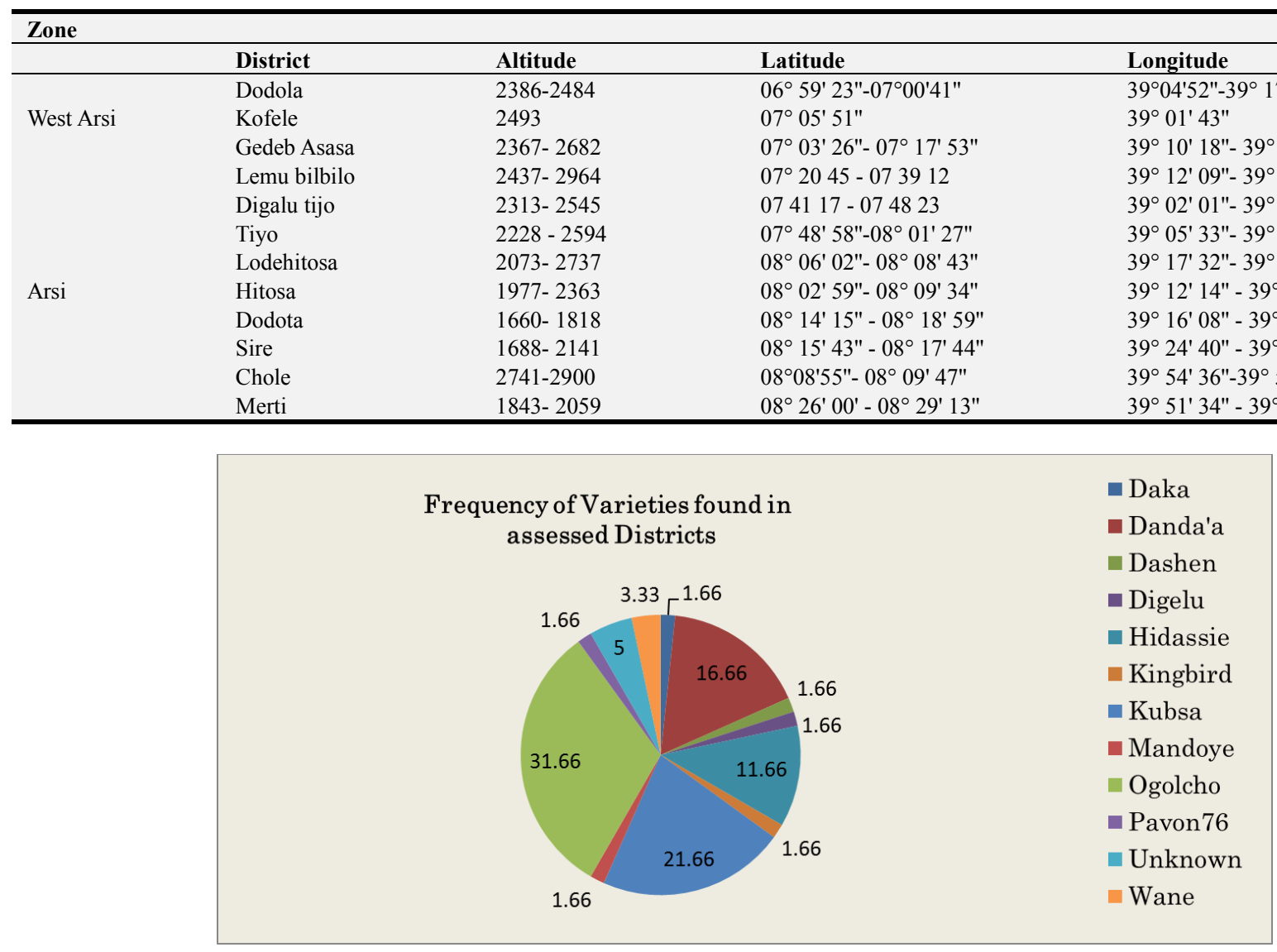

Figure 1. Frequency of varieties/Cultivars in the surveyed Districts.

Disease incidence was calculated by using the number of plants infected and expressed as percentage of the total number of plants assessed. Severity was scored visually using the modified Cobb's Scale [19] for the three rusts, and the double digit scale (00-99) for Septoria leaf blotch [20]. The first scale (0-9) in the double digit scale represents the blotch development up the plant height (5 if the disease reached at the middle height, 8 for flag leaf and 9 for spike), and the second digit stands for severity $(1=10 \%, 2=20 \%$ and $9=90 \%$ ). For each score, the disease severity percentage was calculated based on the following formula [21]. Incidence of FHB was recorded as a percentage of infected wheat spikes
[22], while severity of FHB on wheat spike was recorded following the modified Horsfall-Barrett's scale. Eyespot severity was assessed using a 0-3 rating scale [23] where $0=$ crowns with no infection, $1=$ slight infection $(1-10 \%$ of crowns infected), 2 = moderate infection $(11-40 \%$ of crowns infected), and $3=$ severe infection $(>41 \%$ of crowns infected). Take-all severity was assessed on the same sampled crowns using a 0-5 rating scale [24] with scale values of, $0=$ crowns with no infection, $1=$ trace infection (1-5\% of crowns infected), $3=$ moderate infection $(11-30 \%$ of crowns infected), and $5=$ severe infection $(61-100 \%$ of crowns infected). 


\section{Results and Discussions}

\subsection{Wheat Varieties Grown in Study Districts}

Survey result showed that different wheat varieties cultivated in the study districts (Figure 1). A total of twelve wheat varieties that includes varieties released four decades before (Pavon76) to recently released (Daka) four years ago have grown among the sixty assessed sample farms. The utmost commonly grown wheat varieties in the surveyed districts were Ogolcho and Kubsa taking 31.66\% and 21.66\% respectively. Both Ogolcho and Kubsa varieties were released a decade before but preferred by farmers due to their yield and quality [25]). Unlike their distribution, the varieties were highly susceptible to yellow rust thereby leave extra cost to growers for purchasing fungicides [26] for instance farmers sprayed one to four times in 2020 growing season. On contrary, varieties namely, Daka, Pavon 76, Dashen, Digelu and Mandoye were encountered on a single field in the study areas.

\subsection{Distribution of Rusts and Septoria Leaf Blotch}

The survey result indicated that the mean incidence of foliar diseases (yellow rust, stem rust and septoria leaf blotch) in the assessed fields were $92.7 \%, 11.8 \%$ and $100 \%$ respectively. Of the three foliar diseases, septoria leaf blotch is highest in cases of incident. Yellow rust and septoria leaf blotch were vastly observed since there was conducive weather condition in 2020 growing season. Although the maximum diseases incidence was recorded due to septoria leaf blotch, relatively higher disease severity that may probably be poses huge yield losses was associated with yellow rust. According to reports of [27, 28]; septoria leaf blotch is among the major wheat production bottlenecks in many growing areas causing $42 \%$ economic losses yearly while stem and yellow rusts cause about 100\% [29] loss in Ethiopia depending on the susceptibility of the variety, time of initial infection and virulence of strain.

Generally, the incidence range for yellow rust, stem rust and septoria leaf blotch were 0-60 S, 0-20 MS and 100 respectively. While the severity range of the aforementioned foliar diseases was laid between 0-60, 0-20 and 22-66 in their order.

\subsection{Head Blight, Foot and Root Disease}

\section{Fusarium head blight}

Of the 60 fields inspected, fusarium head blight was observed on 19 (31.66\%) wheat farms, of which Digelu tijo and Sire were the foremost districts regarding disease incidence on varieties of Hidassie and Ogolcho respectively. Similar trends were recorded regarding the severity of the disease (Table 2) and (Figure 2). This may be due to the occurrence of favorable environment to the pathogens and relatively higher susceptible nature of the host varieties. [30], reported that FHB incidence of 0 to $35 \%$ at farmer's fields 0 to $56 \%$ at experiment stations, and 0 to $57 \%$ at seed production fields and 0 to $84 \%$ at state farms was recorded in Kulumsa areas. In contrast cultivars from Kofele, Tiyo and Chole were found free from fusarium head blight (Table 2).

Table 2. Summary of diseases incidence and severity in surveyed areas.

\begin{tabular}{|c|c|c|c|c|c|c|c|c|c|c|c|c|c|}
\hline \multicolumn{14}{|l|}{ Zone } \\
\hline & \multirow{2}{*}{ District } & \multicolumn{2}{|c|}{ Yellow rust } & \multicolumn{2}{|c|}{ Stem rust } & \multicolumn{2}{|c|}{ Septoria tritici } & \multicolumn{2}{|l|}{ FHB } & \multicolumn{2}{|c|}{ Eye spot } & \multicolumn{2}{|c|}{ Take-all } \\
\hline & & Ince. & Sev & Ince & Sev & Ince. & Sev. & Ince. & Sev. & Ince. & Sev. range & Ince. & Sev. range \\
\hline \multirow{6}{*}{ W. Arsi } & Dodola & 100 & 6 & 50 & 2 & 100 & 31.5 & 1.3 & 50.6 & 75 & $0-3$ & 66.6 & $0-5$ \\
\hline & Kofele & 100 & 5 & 0 & 0 & 100 & 40 & 0 & 0 & 0 & 0 & 0 & 0 \\
\hline & Gedeb Asasa & 100 & 11.7 & 0 & 0 & 100 & 25 & 0.33 & 20 & 50 & $0-2$ & 50 & $0-1$ \\
\hline & Lemu bilbilo & 100 & 21.4 & 0 & 0 & 100 & 35.7 & 0.2 & 60 & 57.1 & $0-1$ & 57.1 & $0-1$ \\
\hline & Digalu tijo & 100 & 23.6 & 0 & 0 & 100 & 32.8 & 10.42 & 66.6 & 57.1 & $0-3$ & 57.1 & $0-5$ \\
\hline & Lodehitosa & 83.3 & 12.5 & 16.6 & 3.3 & 100 & 31.6 & 0.33 & 60 & 83.3 & $0-2$ & 100 & $1-2$ \\
\hline \multirow[t]{6}{*}{ Arsi } & Hitosa & 100 & 4.6 & 0 & 0 & 100 & 30 & 0.14 & 20 & 28.3 & $0-2$ & 28.5 & $0-3$ \\
\hline & Dodota & 80 & 3 & 25 & 0.83 & 100 & 52 & 1 & 40 & 50 & $0-1$ & 75 & $0-1$ \\
\hline & Sire & 100 & 23 & 50 & 6.3 & 100 & 25 & 1.5 & 25 & 75 & $0-2$ & 75 & $0-2$ \\
\hline & Chole & 50 & 5.25 & 0 & 0 & 100 & 20 & 0 & 0 & 0 & 0 & 0 & 0 \\
\hline & Merti & 100 & 11 & 0 & 0 & 100 & 26 & 1.2 & 24 & 66 & $0-1$ & 80 & $0-1$ \\
\hline & Grand mean & 92.7 & 11.9 & 11.8 & 1.1 & 100 & 31.6 & 1.4 & 30.5 & 48.5 & $0-3$ & 52.4 & $0-5$ \\
\hline
\end{tabular}

$\mathrm{Sev}=$ severity; $\mathrm{FHB}=$ fusarium head blight; Ince=Incidence.

Take all and Eyespot

Survey results showed that out of 12 districts assessed during the field inspection, maximum infestation of $100 \%$, $80 \%, 66.6 \%$ for diseases incidence and severity range of $1-2$, $0-1$ and $0-5$ to take all was recorded at Lode-hitosa, Merti and Dodola respectively.

The incidence of eyespot was $83.3 \%$ at Lode-hitosa, $80 \%$ at Merti, $75 \%$ at Sire and $66 \%$ at Dodola for incidence was recorded. Eyespot diseases severity was highest at Dodola, Digalu-tijo and Tiyo where relatively lower incidence was observed. While, both take all and eyespot diseases were not recorded at at Kofele and Chole districts. The districts where maximum diseases incidence and severity recorded were area wheat monocroppig are highly practiced (Hunde, 2003).

Take-all and eyespot are yield and quality incurring diseases of small grain cereals in various areas of the globe where crop rotation is absent. Since the pathogens are soil- 
and debris-borne, harvest residue is a main inoculum transferor [31]. In Ethiopia, survey reports indicated that both eyespot and take-all diseases are prevalent in wheat farms which able to cause up to $29 \%$ yield losses [32].

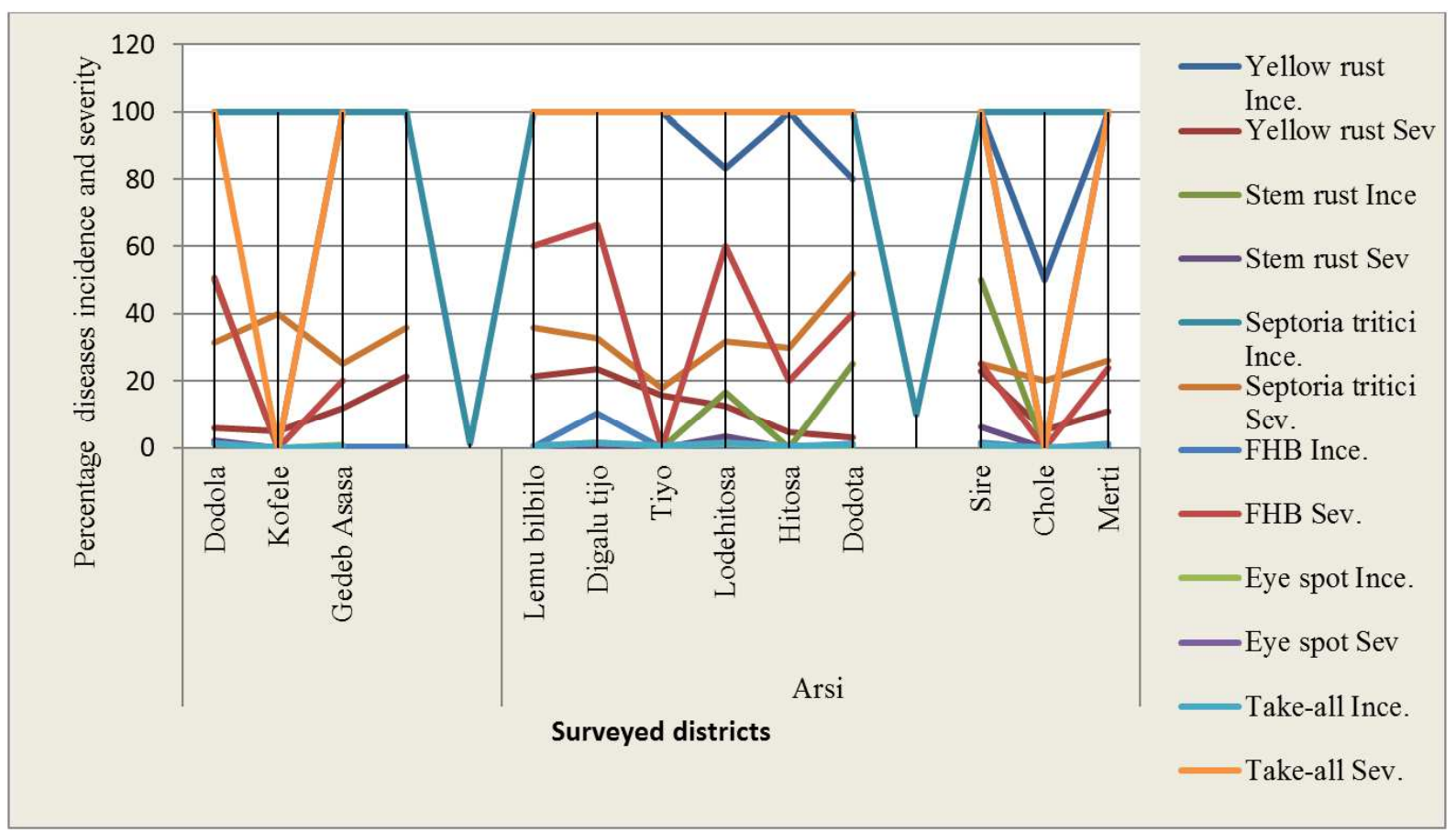

Figure 2. The relative diseases incidence and severity along the surveyed districts.

\section{Conclusion and Recommendations}

The result of current investigation showed that majority of the cultivated commercial wheat varieties like Ogolcho, Kubsa and Danda'a were old and susceptible to both yellow and stem rust diseases but occupied large geographic areas. On contrary, newly released rust tolerant and high yielding wheat varieties like Daka were obtained in a lesser extent. Therefore, it is advisable to disseminate improved and newly released varieties in order to reduce economic threat associated with rusts and decline chances of new mutant races of rusts. Similarly, the survey revealed foot (eye-spot) and root (take-all) diseases were relatively severed in farms where cereal monocropping were common. Thus, stubble management and rotation or cropping sequencing practices have to be effectively addressed to minimize trash-borne diseases.

\section{References}

[1] Awika J. (2011). Major Cereal Grains Production and Use around the World ACS Symposium Series 1089: 1-13 DOI: 10.1021/bk-2011-1089. ch001.

[2] Curtis, B. C. (2002) Wheat in the World. In: Curtis, B. C., Rajaram, S. and Macpherson, H. G., Eds., Bread Wheat Improvement and Production, Plant Production and Protection Series 30, FAO, Roma, 1-18.

[3] Braun, H. J., Atlin, G. and Payne, T. (2010). Multi-location testing as a tool to identify plant response to global climate change. In: Reynolds, CRP.(ed.). Climate change and crop production, CABI, London, UK.

[4] HGCA (2014). Prospects: IGC, 2014 wheat harvest area estimates. Wheat-harvest area estimates. aspx. Accessed 2 April 2014.

[5] ICARDA. (2012). ICARDA Annual Report 2011. International Center for Agricultural Research in the Dry Areas, Aleppo, Syria. IV, 52 pp.

[6] Kumar U, Joshi AK, Kumar S, Chand R, Röder MS. (2011). Quantitative trait loci for resistance to spot blotch caused by Bipolaris sorokiniana in wheat (T. aestivum L.) lines 'Ning 8201' and 'Chirya 3'. Molecular Breeding: 26 (3): 477-491.

[7] FAOSTAT (2014). FAOSTAT agriculture data http://faostat3.fao.org/

[8] Ashamo M., Tewodros M. and Yasin G. 2012. Participatory On-Farm Evaluation of Improved Bread Wheat Technologies in Some Districts of Southern Ethiopia. Journal of Biology, Agriculture and Healthcare: Vol 2, No. 4.

[9] Shiferaw B., Smale M., Braun J., Duveiller E., Reynolds M. \& Muricho G. (2013). Crops that feed the world. Past successes and future challenges to the role played by wheat in global food security. Food Sec. (2013) 5: 291-317.

[10] Alemayehu Hailu Welderufael, Getaneh Woldeab Wolderufael, Woubit Dawit Bedane, Endale Hailu Abera, (2015). Evaluation of Bread Wheat Varieties to Dominant Races of Stem Rust (Puccinia graminis $f$. sp. Tritici) Pathogen, Science Innovation. Vol. 3, No. 6, 2015, pp. 121126. doi: 10.11648/j.si.20150306.20.

[11] CSA (2019). Agricultural Sample Survey: Report on area and production of major crops, centeral statistical agency, Addis Ababa Ethiopia. 
[12] Nelson KM (2013). Analysis of Farmer Preferences for Wheat Variety Traits in Ethiopia: A Gender-Responsive Study. MSc Thesis, Cornell University. USA.

[13] Beyene B. (2018). Status and Challenges of Wheat Stem Rust (Puccinia Graminis F. Sp. Tritici) and Threats of New Races in Ethiopia. International Journal of Forestry and Horticulture (IJFH) Volume 4, Issue 4, 2018, PP 22-31.

[14] Singh A., Gautam S., Singh R. and Paliwal D. (2005). Ergonomic study of farm women during wheat harvesting by improved sickle. African Journal of Agricultural Research. Vol. 9 (18), pp. 1386-1390.

[15] Milus A., Kristensen K. and Hovmoller S. (2009). Evidence for increased aggressiveness in a recent widespread strain of Puccinia striiformis f. sp. tritici causing stripe rust of wheat. Phytopathology 99 (1): 89-94.

[16] Badebo A, Andarge A, Girma B, Payne T (2001) Double sources of resistance to Puccina striiformis and P. graminis f. sp. tritici in CIMMYT bread wheat lines. In: Proceedings of the 9th Biannual conference, 22-23 June 1999, Addis Ababa Ethiopia. Crop Science Society of Ethiopia, Addis Ababa, Ethiopia.

[17] Hailu G, Tanner DG, Mengistu H (2011). Wheat research in Ethiopia: A Historical perspective, IARI and CIMMYT, Addis Ababa.

[18] Abebele GM, Admasu MA, Agdu BH (2020). Field Evaluation of Bread Wheat (Triticum aestivum L.) Genotypes for Stripe Rust (Puccinia striiformis W.) Resistance in Arsi Highlands of Oromia Region, South -Eastern-Ethiopia. J Plant Pathol Microbiol 11: 521.

[19] Peterson RF, Campbell AB, Hannah A (1948). A diagrammatic scale for estimating rust intensity on leaves and stems of cereals. Canadaian Journal Research 26: 496-500.

[20] Eyal, Z, Scharen AL, Prescott JM, Van Ginkel M (1987). The Septoria diseases of wheat: Concepts and methods of disease management. CIMMYT, Mexico DF, Mexico.

[21] Sharma RC, Duveiller E (2007) Advancement toward new Spot Blotch resistant wheat in south Asia. Crop Science 47: 961-968.

[22] Wegulo, S., Jackson, T., Baenziger, P., Carlson, M. \& Nopsa, J., (2008). Fusarium head blight of wheat. University of Nebraska-Lincoln Extension.
[23] Scott, P. R. and Hollins, T. W. (1974). Effect of eyespot on the yield of winter wheat. Annals of Applied Biology 78: 269-279.

[24] Scott, P. R. (1969). Control of Ophiobolus graminis between consecutive crops of winter wheat. Annals of Applied Biology 63: 47-53.

[25] Hei Netsanet, Hussein Ali Shimelis and Mark Laing. (2016). Appraisal of farmers' wheat production constraints and breeding priorities in rust prone agro-ecologies of Ethiopia. African Journal of Agricultural Research, Vol. 12 (12), pp. 944-952, 23 March, 2017 DOI: 10.5897/AJAR2016.11518.

[26] Bekele Hundie Kotu, H. Verkuijl, W. Mwangi, and D. Tanner. (2000). Adoption of Improved Wheat Technologies in Adaba and Dodola Woredas of the Bale Highlands, Ethiopia. Mexico, D. F.: International Maize and Wheat Improvement Center (CIMMYT) and Ethiopian Agricultural Research Organization (EARO).

[27] Takele A, Lencho A, Getaneh WA, Hailu E and Kassa B (2015). Status of wheat Septoria leaf blotch (Septaria tritici Roberge in Desmaz) in south west and Western Shewa zones of Oromiya regional state, Ethiopia. Research in Plant Sciences 3 (3): 43-48.

[28] Said A and Hussein T (2016). Epidemics of Septoria tritici blotch and its development overtime on bread wheat in Haddiya-Kambata area of Southern Ethiopia. Journal of Biology, Agriculture and Health Care 6 (1): 47-57.

[29] Meyer M, Bacha N, Tesfaye T, Alemayehu Y, Abera E, Hundie $\mathrm{B}$, et al. (2021). Wheat rust epidemics damage Ethiopian wheat production: A decade of field disease surveillance reveals national-scale trends in past outbreaks. PLoS ONE 16 (2): e0245697. https://doi.org/10.1371/journal.pone.0245697

[30] Bekele, E. \& Karr, A., (1997). Fusarium head blight in Ethiopian wheat and the identification of species causing the disease. Pest Management Journal of Ethiopia (Ethiopia).

[31] Jenkyn, J. F. and Plumb, R. T. (1981). Strategies for the Control of Cereal Disease. Federation of British Plant Pathologists, London, England.

[32] Eshetu Bekele and Yitbarek Semeane. 1983. Occurrence of eyespot and preliminary loss assessment study in wheat and barley around Holetta, Ethiopia. Ethiopian Journal of Agricultural Science 5: 97-107. 